\title{
Visual perception verbs and degrees of certainty in Turkish: The case of görünmek and gözükmek
}

\author{
Zeynep ERK EMEKSIZ \\ ORCID ID: 0000-0002-6766-7219 \\ Johannes Gutenberg-Universität Mainz \\ zemeksiz@uni-mainz-de
}

(Received 3 May 2021; Accepted 29 October 2021)

\begin{abstract}
This study aims at describing the meaning extensions and functions of the object-oriented see type verbs 'görünmek' and 'gözükmek' in Turkish in terms of the evidential status and epistemic stance they encode. The observations of this research are based on corpora obtained from Turkish National Corpus.The results indicate that görün- and gözük- share some common features in terms of their functions in discourse. They are both used evidentially with indirect evidence. TNC corpus in general shows that görünin Turkish presents a dichotomous structure from subjective to intersubjective forms. The subjective forms 'görün-, gibi görün' have the highest usage of the objective personal pronoun 'bana' and the possessive form 'gözüme' indicating the involvement of the speakers/writers to the situation presented. When speakers/writers present their utterances in intersubjective point of view, they prefer the parenthetical forms such as 'görünen o ki' without any objective personal pronouns involved. This suggests that speakers/writers do not take the responsibility of the truthiness of their utterances in intersubjective mode.

Keywords: visual perception, verbs, Turkish epistemic stance, certainty, evidentiality
\end{abstract}

\section{Türkçede görme algı eylemleri ve kesinlik derecelenmesi: Görünmek ve gözükmek}

ÖZ: Bu çalışmanın amacı Türkçede nesne algı eylemleri olan görün- ve gözük'ün anlamsal genişlemelerini ve söylemdeki işlevlerini bilgi kaynağına karşı olan tutumları ve kanıtsallık açısından betimlemektir. Çalışmanın bulguları Türkçe Ulusal Derlem'e dayanmaktadır. Çalışmanın sonuçları her iki eylemin de benzer anlamsal genişlemeler ve söylem işlevleri taşıdıklarını ancak görünmek eyleminin daha çok tercih edilen biçim olduğunu göstermektedir. Kanıtsallık açısından, her iki eylemin de dolaylı kanıta dayalı önermeler için 
kullanıldığ 1 gözlenmektedir. Görünmek eylemi, konuşmacıların/yazarların bilgi kaynağına karşı tutumu açısından öznelden özneler arası tutuma doğru ikili bir yapı taşımaktadır. TUD verilerine göre görün- en fazla nesne adılları (bana/bize) ve iyelik çekimi gösteren 'gözüme/gözümüze' ile eşdizilimli görünmektedir. Dolayısıyla görün-ana tümcenin eylemi olduğunda konuşmac1/yazar bilgi kaynağ1 olarak kendini sözcesine eklemekte ve daha öznel bir bakış açısı sunabilmektedir. Ancak 'görünen o ki' ve ‘öyle görünüyor ki' gibi ara sözceler özneler arası bakış açısıyla kullanılmaktadır ve bilgi kaynağına dair herhangi bir işaret içermemektedir. Bu gözleme dayanarak konuşmacıların/ yazarların ara sözce biçimlerini kullanarak önermelerinin bilgi kaynağıyla ilgili sorumluluk almadıklarını ve bir söylem stratejisi olarak kaçamaklama yaptıklarını söylenebilir.

Anahtar Sözcükler: görme alg1 eylemleri, Türkçe bilgi tutumu, kesinlik, kanitsallik

\section{Introduction}

The verbs of visual perception receive an increasing attention in the literature since they encode the evidential status of speakers/writers, (S/W) namely how they have access to the information they refer to in a given speech situation and their subjectivity (Picoche, 1986; Traugott, 1995; de Haan, 2007; Aijmer, 2009; Diewald and Smirnova, 2010; Whitt, 2010; Grossman and Tutin, 2012). Most of these works focus on 'see' and 'seem' verbs in the languages that evidentiality is not grammaticalized such as French (see Picoche, 1986; Grossman and Tutin, 2012; Renate, 2012), English (see Traugott, 1997; Aijmer, 2009) and German (see Diewald, 2010; de Haan,2007; Whitt, 2011), and different syntactic forms of these verbs have been examined in order to describe how S/Ws encode the source of information and their subjectivity/intersubjectivity.

Although the evidential aspect of these verbs have been studied at length, the relation between the evidential meaning and the speakers/writers levels of certainty-namely epistemic modality- towards their propositions has been slightly described. In a language in which evidentiality is grammaticalized like Turkish, the use of 'see and seem type verbs' in various evidential conjugations results in a rank of degrees of certainty.

The primary purpose of this study is to describe the meaning extensions of 'görünmek' and 'gözükmek' in Turkish discourse. We will specifically focus on the evidential and epistemic meanings that the verb 'görün-' encodes and investigate how S/Ws reflect their subjectivity.

This paper is organized as follows: Section 2 introduces definition of the terms related to perception verbs and evidentiality. Although there is a stockpile of research on evidentiality and epistemic modality, these terms have been used somehow intriguing and there is no consensus on the terminology. Hence, we need to clarify how we use these terms in our study. Section 3 is devoted to 
methodology and data. Section 4 will present the correlation between evidential and epistemic meanings of 'görün-' in discourse. Our observations are based on the naturally occurring data extracted from Turkish National Corpus (TNC), with a size of 50 million words.

\section{Definition of the Terms}

\section{1 Verbs of Visual Perception: Görmek, Görünmek and Gözükmek}

In his typological study, Viberg (1983) states that perception verbs have two arguments, the experience of perception $\mathrm{E}$, and the stimulus/object of perception $\mathrm{S}$. He classifies the perception verbs into two basic categories as experiencerbased and phenomenon-based verbs. Whitt (2010) calls experiencer-based verbs as subject-oriented and phenomenon-based verbs as object-oriented. Subject oriented perception verbs are transitive and have both of the arguments $\mathrm{E}$ and $\mathrm{S}$. They select $E$ as the subject of the sentence and $S$ as the object of perception. Note that grammatical subjects correspond to 'experiencer' in Viberg's terminology. The subject oriented verbs are further divided into two types depending on the semantic role they assign to their subjects. Look and listen type verbs selects agentive subjects who intentionally perceive things. On the other hand, see and hear type verbs select experiencer as the subject who is simply exposed to the situation and perceives it. Hence, the verb 'to look' has the feature [+control] while 'to see' possesses [-control]. Using the terminology provided by Viberg and Whitt, Figure 1 below introduces the visual perception verbs in Turkish in terms of the basic semantic feature [+/-control]:

Figure 1. Visual perception verbs in Turkish

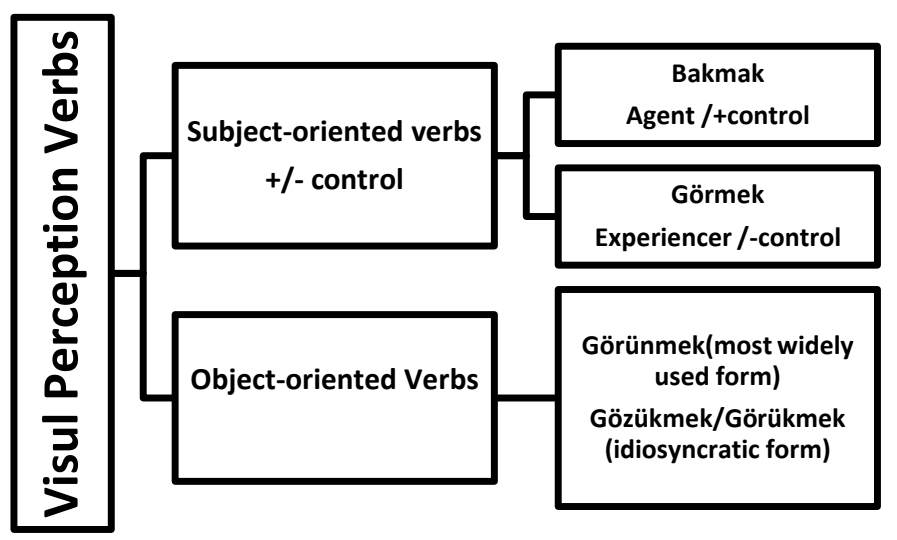


The verb 'gör-' in (1) is an experiencer type subject oriented verb corresponding to 'see' verb in English.

(1) Ayşeyi hasta gör-dü-m.

Subject -adj. -Verb-Perf. -1st Pers. Sing.

I saw Ayşe sick.

The object oriented verbs, on the other hand, select $\mathrm{S}$ as their subjects and $\mathrm{E}$ is left outside. 'seem' type verbs are object oriented since the grammatical subject is the object of perception. However, it is possible to add the experiencer as an object pronoun as illustrated in (2).

(2) Ayşe bana hasta görün-dü.

Subj - obj. Pro.-adj.- Verb-Perf.

Ayşe seemed sick to me.

As Whitt puts it, the distinction Viberg provides is essential for detecting evidential meanings since the object oriented seem type verbs are always subject to evidentiality while subject oriented see type verbs have evidential meanings only when they are attached to an event witnessed by the speaker.

\subsection{Evidentiality and Epistemic Modality}

Evidentiality and epistemic modality are somehow intertwined as illustrated in (3) and (4):

(3) I see that John is ready to leave.

(4) John seems to be ready to leave.

In (3), the S/W infers that John is ready to leave depending on what he/she perceives about his leaving (maybe the speaker simply depends on direct visual evidence seeing him in front of the door or his deduction from different kinds of evidence like he packed his baggage, bought the ticket, etc.). The type of the evidence used also implicates a degree of certainty of the speaker about his proposition on John's leaving. Since the subject oriented visual perception verb 'gör-'is used, it has a higher degree of certainty when compared to 'John seems to be ready to leave' in (4).

Boye (2012) presents a very comprehensive overview of the approaches to evidentiality and epistemic modality in his typological work. He states that there are two major approaches to define the relation between evidentiality and epistemic modality in the literature: The inclusion view, one of the notions is considered to be the subcategory of the other. Some researchers prefer defining 
evidentiality as a subcategory of epistemic modality (Palmer 2001; Willett 1988), and some other vice versa (Papafragou, 2000). The other one is the disjunction view, taking the two categories separate but somehow related (Aikhenvald, 2004; de Haan, 1999; Plungian, 2011). I will use the term evidentiality for 'the ways that speakers had access to the information referred to in a particular speech situation' as described in Plungian (2011):

Direct access refers to any means of obtaining information that presuppose a direct perception of a situation by the speakers (mainly visual, but not necessarily) and/or direct participation of the speakers in a situation. Indirect access, on the other hand, presupposes that the knowledge about a situation was obtained through other means: The speaker did not observe the situation in a direct way and did not participate it. (p.29)

Plungian also uses the terms 'personal and non-personal accesses' to information. Personal access is the speakers' direct involvement to the situation. When the speakers have non personal access, they base their utterance to some other sources, either another person (a hearsay) or a logical conclusion based on some evidence. Here I would like to introduce another term, subjectivity which is related to speakers' involvement to the situation. Elaborating Nuyts' work on subjectivity, Whitt (2010) argues that the difference between subject oriented experiencer type visual perception verbs and object oriented verbs is that the latter is intersubjective while the former is subjective. Whitt uses the term 'intersubjective' for the situations in which the evidence is available not only to the speaker but also to a larger speech community.

It is beyond the scope of this study to argue which of the views is more applicable to naturally occurring data, however, we should keep in mind that there is a certain relation between the certainty level and the evidential status of the utterance. Here I adopt the disjunction view and define evidentiality and epistemic modality as two distinct but related terms. In its broadest sense, certainty is a notion related to speakers judgments about the truth of an assertion. As Nuyts defines 'epistemic modality, or certainty, concerns a linguistic expression of an estimation of the likelihood that a certain hypothetical state of affairs is, has been, or will be true' (Nuyts, 2001, p. 27). Certainty can be defined on a continuum from high certainity to low certainty, or uncertainty (Rubin et al. 2004, 2006).

Now, let's focus once again on the utterance in (1) and (2) presented earlier to observe in what ways evidentiality and certainty are related to each other:

(1). Ayşeyi hasta gördüm.

(2). Ayşe (bana) hasta göründü /gözüktü. 
In (1), using the subject oriented verb 'gör-' the speaker ensures that he/she has personal and direct access to information he gives and the utterance has a high level of certainty. On the other hand, the speaker in (2) uses the verb 'görün-' and Ayşe becomes the grammatical subject of the utterance. In both cases, it is obvious that the speaker has direct access to information since he is the one who sees Ayşe. However, in (2), although there is a direct visual access, the speaker is not involved to the situation. He/she encodes that what he/she said depends on the logical conclusion he/she made with some evidence such as 'she looks pale, and tired, etc. Hence, the utterance has a lower level of certainty when compared to first one.

\section{Methodology and Data}

This research mainly uses data obtained from Turkish National Corpus (TNC). TNC consists of 50 million words providing corpora both in written and spoken contemporary Turkish. (www.tnc.org.tr). In order to describe meaning extensions of görün-and -gözük in discourse, various conjugated forms of these verbs were investigated in TNC (Aksan and aksan, 2016). The findings are based on the frequency and collocational patterns. Table 1 illustrates the standart querry results for görün- and gözük- in various conjugated forms. The verb forms and their occurrences in TNC are as follows: 
Table 1: Distribution of görün- and gözük- in TNC

\begin{tabular}{|c|c|c|c|c|c|}
\hline \multicolumn{2}{|c|}{ Verb Forms } & \multicolumn{2}{|c|}{ Number of Texts } & \multicolumn{2}{|c|}{ Observed Frequencey } \\
\hline & & Spoken & Written & Spoken & Written \\
\hline \multirow{6}{*}{ 竞 } & görün-dü & 1 & 469 & 1 & 790 \\
\hline & görün-ür & 6 & 804 & 6 & 1516 \\
\hline & görün-üyor & 32 & 1103 & 47 & 2685 \\
\hline & görün-mektedir & 3 & 548 & 3 & 1008 \\
\hline & görün-üyordu & 3 & 648 & 3 & 1477 \\
\hline & görün-ecek & 2 & 101 & 2 & 118 \\
\hline \multirow{6}{*}{ 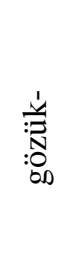 } & gözük-tü & 1 & 86 & 1 & 112 \\
\hline & Gözük-ür & 5 & 93 & 6 & 127 \\
\hline & gözük-üyor & 17 & 318 & 21 & 514 \\
\hline & gözük-mektedir & 2 & 272 & 2 & 505 \\
\hline & gözük-üyor-du & 3 & 131 & 3 & 235 \\
\hline & gözük-ecek & 0 & 16 & 0 & 17 \\
\hline
\end{tabular}

We should note here that the frequency of 'gözük-' is very low when compared to 'görün-' in both written and spoken corpora.

There are 3 object-oriented verbs in Turkish. 'görün-' is derived from 'gör' by the reflexive suffix -In, a suffix also used for passivization in Turkish. The origin of the verb goes back to 'köz-e', and 'köz-ü-n' in Old Turkic (Erdal, 1991). As for the derivation of 'gözük', we have the form 'közük' in old Uyghur texts. However, there is no instance of the verb in Old Anatolian Turkish till $14^{\text {th }}$ century. 'görük' is sparse but it is still possible to see it in some of the dialects spoken in Turkey. Since it is really sparse and does not exist in the corpus, I omitted this variation. TDK online dictionary presents 'gözük-'as the synonym of görün-. The entry for this verb is as follows:

\section{gözükmek: (nsz) Görünmek: Bazen hareketleriyle pek makul, bazen âdetleriyle garipvegülünçgözükürmüş. A.Ş.Hisar. (http://www.tdk.gov.tr/index.php?option=com_bts\&arama=kelime\&gui d=TDK.GTS.53fc7dfd197057.53028463)}

Both of these verbs mean 'to appear/ to show one's face, etc.'as in (5) and (6). They also function as a copular verb as in 'Ayşe hasta göründü/gözüktü' (Ayşe looks pale)'. They take adjectival complements to reflect S/Ws judgements on a given situation as in (7) and (8). We should also note here that both (7) and (8) reflect evidential meanings. They are used to express the speakers' inference and judgments based on piece of evidence in a certain situation. In (7), the S/W 
assumes that something is difficult to manage and using the verb 'görün-' he/she states that this assumption relies on his/her inference rather than direct evidence. Likewise, S/W in (8) must have reasons to draw the conclusion that the government must be changed. When we consider their evidential function, we can state that görün- and gözük- are seem type verbs corresponding to 'seem to be' in English (see Aijmer, 2009 for features of seem to and evidentiality in English).

(5) Physical appearance (to appear/ to occur)

Abla balkonda göründü. (TNC W-IA16B2A-2674-468)

(The elder sister appeared in the balcony).

(6) Aliye....kapıda gözüktü. (TNC W-MA16B3A-0039-36)

(Aliye appeared at the door).

(7) Speakers' judgements on a given situation (seem to be)

Şu an için biraz zor görünüyor. (TNC W-QH42C3A-3331-1964)

(For now, it seems to be difficult)

(8) Bu hükümetin değişmesi şart gözüküyor (TNC W-SG43C2A-1808-425)

(It seems to be a must to change this government)

There is one certain difference between these verbs is that 'gözük' is less preferred when compared to 'görün' in TNC results. When we browse the verbs with different conjugations such as 'göründü, görünmektedir, görünüyor' and 'gözüktü/gözükmektedir/gözüküyor' we obtain less results. For example, when we browse 'görün' in past tense conjugation as 'göründü' we obtain 790 hits out of 418 different texts while we have only 112 hits in 86 different texts for 'gözüktü' in TNC. They both highly occur in imaginative prose and rarely occur in scientific discourse. However, görün- is more productive than 'gözük'. All the proverbs and phrasal verbs are derived from 'görünmek' in TDK dictionary. We should also note that we have 'görünen o ki, göründüğü kadarıyla, 'görünüş' forms derived from 'görün-' while 'gözüken o ki' 'gözüktüğü kadarıyla' 'gözüküş' does not exist.

TNC results also show that there is a correlation between conjugation forms and the frequency rates in the corpora. As for görün-, the progressive form 'görünüyor/gözüküyor' enjoys the highest amount (2685/514) while future tense conjugation has the lowest frequency (118).

\section{Evidential and Epistemic Meanings of 'görün-'}

We have basically 5 collocational patterns that occur in the corpus frequently with the verb 'görün-'in TNC. First one is the case that the speaker encodes that he has direct access to the situation with the indirect (dative) object pronoun 
'bana' (to me) and 'gözüme' (to my eyes) following the pattern ' $\mathbf{X}$ to $\mathbf{m e} / \mathbf{t o} \mathbf{m y}$ eyes Y görün' as illustrated in (9) and (10):

(9) $\mathrm{Bu}$ iş bana çok kolay göründü.

(This seems to be very easy to me TNC, EA16B2A-0744).

(10) Gözüme çok üzgün göründü.

(He seem to be very sorry to me. TNC, QD36E1B-2841)

Both of the examples show that the S/Ws do not have a direct access to the evidence, rather they infer it from the situation. However, (9) differs from (10) in terms of the type of the evidence. In (9), the S/W draws a conclusion based on some abstract evidence (perhaps his previous experience). In (10), on the other hand, he/she draws a conclusion based on how the subject looks like, a piece of concrete evidence. We should also note here that the speakers also mark their involvement to the situation. Since the $\mathrm{S} / \mathrm{W}$ can add his/her subjectivity to the utterance with the indirect object pronoun and the possessive form, it is possible to conclude that they are involved into the situation. Obviously, they also take the responsibility of what they said.

The second collocational pattern in TNC includes a postpositional phrase headed by 'gibi' (corresponding to 'as' in English). This form follows the pattern 'X (to me/to my eyes) Y gibi görün-'. There are two discourse contexts that this form appears in the data: First one is related to the contexts in which the speaker describes the situation over a metaphor as illustrated in (11). The S/W describes the object over a person who is a bomb expert and uses the form 'gözüme gibi görün'.

(11) Nedense o an gözüme, konsantrasyonunun bozulmasını istemeyen bir bomba imha uzmanı gibi göründü.

(I don't know why, he suddenly seemed to me as if he was a bomb expert on who didn't want to lose his concentration TA16B3A-3348)

This pattern is also related to the situations in which the $\mathrm{S} / \mathrm{W}$ wants to decrease the certainty level of their logical inference about a situation. In (12), using 'zayif gibi görün-' the speaker reflects that he is not totally certain whether the subject can be considered to be slim completely in comparison to some other person.

(12) Biraz zayıf gibi göründü bana. Senin gibi biraz kilo almalı canım. (She looks slim. She had better to gain weight as you did.EA16B2A1740) 
'gibi görün-' highly occurs with the concessive marker 'ama' in discourse. This structure can be a mark of concessive relation in Turkish discourse:

(13) Belki bu çok ufak bir olay gibi görünüyor ama kesinlikle küçük bir şey değil. $\mathrm{O}$ anda bana yapılan saygısızlıkt. (Maybe it seems as if it is nothing, but it really matters. They behaved me disrespectfullyJI37C3A0091).

In concessive contexts, the speakers/writers use others' stance using 'gibi görün-' and state their own perspective in the concession clause starting with 'ama', 'fakat', 'oysa', 'ancak'. It is also noticeable that this use of 'görün-' highly occurs in argumentative discourse as a part of the claim structure. The S/Ws uses this pattern to reflect 'others' point of view which is opposing to their own ideas.

There are three more evidential forms that 'görün' is frequently used:

1. 'öyle görünüyor ki' 'it seems that' 'it seems to be so that...'

2. 'görünen o ki' 'seemingly / it would seem that/ apparently...'

3. 'göründüğü kadarıyla' 'apparently/ as far as can be seen'

These forms are parenthetical and used when the S/W presents a logical conclusion, namely his/her inference from non-personal -indirect information. Considering that there is no subject who perceives the situation in these forms, we can conclude that all of them are used intersubjectively. However, 'öyle görünüyor ki' is the only form that the speaker can still mark his involvement using 'bana'. There were total 139 hits of this form in TNC and only 6 of them included 'bana'. This result shows that speakers/writers rarely use this from to mark subjectivity as in the following examples:

(14) Bana öyle görünüyor $k i$, insan tüm kötülükleri -en başta da kendisine yaptıklarını- farkında olmadığı için yapar (It seems to me so that we give harm to ourselves and others unintentionally $\mathrm{TNC}$, TI37C2A-1326)

(15) Görünen o ki, bu Baron denilen haydut, gözünü para hırsı bürümüş çok tehlikeli biri. (Apparently/seemingly, this robber, so called Baron is a very dangerous person. TNC, SA16B2A-0738)

(16) Elektroşok nedir? Göründüğü kadarıyla hastaya çok acı veren bir müdahale (What is electroshockin? It appears to be so that it is an application that gives too much pain to the patient). 
We should note here that there are no instances of these two forms with a subjectivity marker. In other terms, they are used only when the speaker/writers wants to mark intersubjective point of view. Now we can rank these forms in terms of evidential status and certainty levels as illustrated in Figure 2:

Figure 2. Certainty dichotomy from subjective to intersubjective forms

\author{
Subjectivity / Involvement-Higher Certainty \\ - görün- \\ - gibi görün (concessive with others' subjectivity) \\ - $\quad$ öyle görünüyor ki \\ - görünen o ki / göründüğü kadarıyla
}

\title{
Intersubjectivity/ Non-involvement -Lower Certainty
}

Görün- seems to function as a means of lowering the speakers' subjectivity and certainty level in Turkish discourse. Figure 2 presents a dichotomous scale from high level of subjectivity and certainty at the top to lower level of certainty and intersubjectivity. I suggest here that the intersubjective forms of görün- have a pragmatic function which is known as hedging in the literature (Hyland, 1998). When the $\mathrm{S} / \mathrm{W}$ presents his/her utterances in intersubjective point of view, he/she does not take the responsibility of the truthiness of his/her utterances. This strategy also helps the speakers to reflect their epistemic stance to the source of knowledge and piece of evidence they rely on. The verb 'görünmek' and 'gibi görünmek' is well accepted in a situation where the S/W relies on direct visual evidence as in 'yorgun görünüyorsun' (you look tired). However, 'öyle görünüyor ki' and other versions sound odd in such a context since they mark deductions depending on indirect evidence. In the example given, the $\mathrm{S} / \mathrm{W}$ is herself/himself who saw the object and made the deduction that she/he must have worked hard or she must be tired for some other reason.

\section{Conclusion}

The visual object-oriented verbs görün- and gözük- have some common features in Turkish. They both have meaning extensions for appearance and take adjectives as complements to describe either a physical or an abstract state of affairs. These verbs also mark evidential meanings both for direct and indirect evidence. The main difference among them derives from the evidential meaning they mark. görün- is widely used for both direct and indirect evidence in TNC data as in 'Sana cezaevinin yolu görünüyor'. However, gözük- is less preferred form. It is mainly used with physical objects and marks direct evidence as in 'Tepeden bizim ev gözüküyor'. 
TNC corpus in general shows that görün- in Turkish presents a dichotomous structure from subjective to inter-subjective forms. The subjective forms 'görün-' and 'gibi görün-' have the highest usage of the objective pronoun 'bana' and the possessive form 'gözüme' indicating the involvement of the $\mathrm{S} / \mathrm{W}$ to the situation presented. The parenthetical form 'öyle görünüyor ki' also has a few tokens with the objective pronoun, however, it is less preferred when compared to 'bana görün-'form. 'görünen o ki' appears to be the most intersubjevtive form with the lowest certainty level.

\section{References}

Aijmer, K. (2009). Seem and evidentiality. Functions of Language, 16(1), 63-88.

Aikhenvald, A. (2004). Evidentiality. Oxford: Oxford University Press.

Aksan,Yeşim \& Mustafa Aksan (2016) Türkçenin derlem-temelli sıklık sözlüğü: Temel İlkeler ve Uygulama. Uluslarası Sözlük Bilim Sempozyumu Bildiri Kitabı cilt I, 8196

Boye, K. (2012). Epistemic meaning: A crosslinguistic and functional-cognitive study. Berlin: Mouton de Gruyter.

De Haan, F. (1999) Evidentiality and epistemic modality: Setting boundaries. Southwest Journal of Linguistics, 18, 83-101.

De Haan, F. (2007). Raising as grammaticalization: the case of Germanic Seem verbs. Rivista di Linguistica, 19(1), 129-150.

Diewald, G. \& Smirnova, E. (2010). Linguistic realization of evidentiality in European Languages. Berlin-New York: Walter de Gruyter.

Erdal, M. (1991). Old Turkic word formation: A functional approach to the lexicon, I-II. Wiesbaden: Otto Harrassowitz.

Gisborne, N. (2010). The event structure of perception verbs. Oxford: Oxford University Press.

Grossmann, F. \& Tutin, A. (2010). Evidential markers in French scientific writing: The case of the French verb voir. In G. Diewald \& E. Smirnova (Eds.), Linguistic realization of evidentiality in European languages (pp. 279-308). Berlin, New York: Mouton de Gruyter.

Hyland, K. (1998). Hedging in Scientific Research Articles. Amsterdam, Philadelphia: John Benjamins.

Nakamura, F. (2010). Uncovering of rare or unknown usages: a history of seem meaning to pretend. In M. Kytö (Ed.), Language change and variation from Old English to Late Modern English: A festschrift for Minoji Akimoto (pp. 217-238). Berne: Peter Lang.

Nuyts, J. (2001). Epistemic modality, language, and conceptualization: A cognitivepragmatic perspective (Vol. 5). Amsterdam, Philadelphia: John Benjamin Publishing Company.

Palmer, F. (2001). Mood and Modality. Cambridge: Cambridge University Press.

Papafragou, A. (2000). Modality: Issues in the semantics-pragmatics interface. Oxford: Elsevier Science.

Picoche, J. (1986). Structures sémantiques du lexique français. Paris: Nathan. 
Plungian, V. A. (2011). Types of verbal evidentiality marking: an overview. In G. Diewald, \& E. Smirnova (Eds.), Linguistic Realization of Evidentiality in European Languages (pp. 15-58). Berlin - New York: Mouton de Gruyter.

Renata, E. (2012). Les modalités de perception visuelle et auditive: Différences conceptuelles et répercussions sémantico-syntaxiques en espagnol et en français. Berlin-New-york: Walter de Gruyter.

Rubin, V. L., Kando, N., \& Liddy, E. D. (2004). Certainty categorization model. Paper presented at the AAAI spring symposium: Exploring attitude and affect in text: Theories and applications, Stanford, CA.

Rubin, V. L. (2006). Identifying certainty in texts. [Doctoral thesis]. Syracuse University, Syracuse, NY.

Traugott, E. C. (1995) Subjectification in grammaticalisation. In D. Stein, \& S. Wright (Eds.), Subjectivity and Subjectivisation: Linguistic Perspectives (pp. 31-54). Cambridge: Cambridge University Press.

Traugott, E., \& Dasher, R. B. (2002). Regularity in semantic change. Cambridge: Cambridge University Press

Traugott, E. C. (2010). Revisiting subjectification and intersubjectification. In K. Davidse, L. Vandelanotte, \& H. Cuykckens (Eds.), Subjectification, Intersubjectification and Grammaticalization (pp. 29-70). Berlin - New York: Mouton de Gruyter.

Sweetser, E. E. (1990). From etymology to pragmatics: Metaphorical and cultural aspects of semantic structures. Cambridge: Cambridge University Press.

Whitt, R.J. (2010). Evidentiality and perception verbs in English and German. Frankfurt: Peter Lang Verlag.

Willett, T. (1988). A cross-linguistic survey of the grammaticalization of evidentiality. Studies in Language 12(1), 51-97.

Whitt, R.J. (2010). Evidentiality and perception verbs in English and German. Frankfurt: Peter Lang Verlag.

Viberg, A. (1983). The verbs of perception: a typological study. Linguistics, 21(1), 123162. 